\title{
Šiuolaikinių informacinių technologijų naudojimas ir ikimokyklinio amžiaus vaikų miegas
}

\section{R. Praninskiené* \\ R. Jusiené $\dot{e}^{* *}$ \\ I. Laurinaitytè** \\ L. Rakickienè $\dot{*}^{* *}$ \\ L. Petronytè*** \\ V. Urbonas $* * * *$}

*Vaiku ligoniné, Všl Vilniaus

universiteto ligonines

Santaros kliniku filialas,

Vaiku neurologijos skyrius;

Vilniaus universiteto

Vaiku ligu klinika;

Vilniaus universiteto Filosofijos

fakulteto Psichologinio

konsultavimo ir mokymu centras

**Vilniaus universiteto Filosofijos

fakulteto Psichologinio

konsultavimo ir mokymu centras

$* * *$ Vilniaus universiteto

Vaiku ligu klinika

$* * * *$ Vilniaus universiteto

Vaiku ligu klinika;

Vilniaus universiteto Filosofijos

fakulteto Psichologinio

konsultavimo ir mokymu centras
Santrauka. İvadas. Šiuolaikinių informacinių technologijų (IT) naudojimas gali turèti poveikị vaikų fizinei ir psichinei sveikatai. Pirmą kartą Lietuvoje atlikome didelès apimties tyrimą, kad išsiaiškintume ikimokyklinio amžiaus vaikų naudojimosi IT prietaisais ir miego problemų bei miego trukmès sąsajas.

Tiriamieji ir tyrimo metodai. Šiame tyrime išanalizavome 500 vaikų nuo18 iki 72 mèn. amžiaus ( $\mathrm{M}=41,29, \mathrm{SD}=15,44)$ duomenis. $2017 \mathrm{~m}$. balandžio-rugpjūčio mènesiais vaikų tèvai iš ịvairių Lietuvos vietovių užpildẻ popierines ar elektronines tyrèju parengtas anketas. Anketą sudarẻ klausimai apie vaiko raidą ir socialinę aplinką, vaiko naudojimąsi IT prietaisais. Vaiku miego problemos buvo vertinamos pagal Vaiko elgesio aprašo (CBCL/1 1/2-5) Miego sunkumų skalę.

Rezultatai. Atlikto tyrimo rezultatai atskleidè, kad dauguma šio amžiaus vaikų miega 9-10 valandu per naktị. Dieną miega 95,3\% 8 val. ir mažiau naktị miegančiu vaiku ir visi 7 val. ir mažiau naktị miegantys vaikai. Net 77 \% vaikų kasdien miega dieną. Jaunesniems vaikams yra būdingas miego režimas, bet dažnesni prabudimai naktị. Maždaug pusės tyrime dalyvavusių vaikų miego ir poilsio zonose yra bent vienas IT prietaisas. Žemesnio išsilavinimo tėvų vaikai dažniau turi IT prietaisą kambaryje, kuriame miega, ir jiems dažniau leidžiama prieš miegą žiūrèti filmukus. Vaikai, turintys savo kambaryje IT prietaisų, sunkiau užmiega, be to, turi daugiau miego problemų (siekiančių klinikinį miego sutrikimų lygị). Naktị trumpiau miega vaikai, kurie ilgiau naudojasi kompiuteriu darbo dienomis ir laisvadieniais, be to, daugiau laiko leidžia prie ịvairių IT prietaisų ekranų laisvadieniais. Ilgiau prie ekranu būnantys vaikai pasižymi didesne miego sutrikimų rizika.

Išvados. Šis tyrimas atskleidè, kad ankstyvame amžiuje IT prietaisų naudojimas prieš miegą ir jų buvimas tame pačiame kambaryje yra susijęs su miego problemomis, ilgesniu užmigimu ir sutrumpejusiu miegu.

Raktažodžiai: informacinės technologijos, maži vaikai, miego problemos, miego trukmė.

\section{Adresas:}

Rüta Praninskienè

Santariškiu g. 7, LT-08406 Vilnius

El.paštas praninskiene.ruta@gmail.com;

ruta.praninskiene@santa.lt

\section{IVADAS}

Šiuolaikinès informacinès technologijos (kitaip - elektroninès socialinès medijos, tai yra televizorius, planšetè, išmanusis telefonas, kompiuteris ir kiti prietaisai, turintys didesnị ar mažesnị ekraną; IT) ir jų naudojimas tampa neatsiejama vaikų kasdienio gyvenimo ir net ugdymo dalimi. Klinikiniai tyrimai su ikimokyklinio amžiaus vaikais atskleide, kad jie dažnai naudojasi ịvairiais IT prietaisais ir

(C) Neurologijos seminarai, 2018. Open Access. This article is distributed under the terms of the Creative Commons Attribution 4.0 International License CC-BY 4.0 (http://creativecommons.org/licenses/by/4.0/), which permits unrestricted use, distribution, and reproduction in any medium, provided you give appropriate credit to the original author(s) and the source, provide a link to the Creative Commons license, and indicate if changes were made. 
daro tai vis jaunesniame amžiuje [1, 2]. Pasaulinès sveikatos apsaugos organizacija, pediatrų, psichiatrų ir psichologų asociacijos, daugelio šalių mokslininkų grupès ịspejja apie galimą neigiamą IT naudojimo poveikị vaikų fizinei ir psichinei sveikatai [3-5]. Mažų vaikų psichinės sveikatos tyrimų rezultatai rodo, kad pernelyg didelè sensorinè stimuliacija ankstyvame amžiuje siejama su dėmesio sunkumais, bendrai prastesne savireguliacija [6-8]. Manoma, kad didesnis IT naudojimas gali sutrumpinti tèvų ir vaiko tiesioginio bendravimo laiką, kuris ypač svarbus kognityvinei, kalbinei ir emocinei raidai [9]. Tiesa, kai kurie kiti tyrèjai tokio akivaizdžiai neigiamo poveikio nestebi [10] arba pastebi net IT naudojimo privalumą, teigiamą reikšmę vaikų raidai [11]. Vis dèlto vieningai sutariama, kad, jeigu buvimo prie ekranų trukmė yra itin ilga (daugiau nei 0,5 val. vaikams iki dvejų metų ar ilgesnè nei 2 val. vyresniems vaikams), tai jau turi žalingą poveikį. Be to, teigiama reikšmė gali būti stebima tik vyresnių nei trejų metų amžiaus vaikų atveju ir tik tada, kai stebimas turinys atitinka vaiko amžių.

Kalbant apie mažų vaikų fizinės sveikatos ir IT sąsajas, dažnai analizuojamas IT poveikis vaikų miego pradžiai, miego eigai ir trukmei. Laikas, praleistas prie ekranų, siejamas su ilgesne užmigimo, trumpesne bendra miego trukme ir įvairiais miego eigos sutrikimais [12].

Miegas yra aktyvus biologinis procesas, kurị reguliuoja trys pagrindiniai ritmai - cirkadinis, ultradianinis ir homeostazinis. Klinikiniais tyrimais įrodyta, kad ryški, mèlyna įrenginių skleidžiama šviesa, naudojant juos prieš miegą, slopina miego cirkadinio ritmo hormono melatonino gamybą kankorèžinėje liaukoje [13-15]. Dèl ilgesnio laiko, leidžiamo prie ekranų vakare, atsiranda miego cirkadinio ritmo sutrikimų, trumpejja bendroji miego trukmè. Neabejotinas poveikis ultradianiniam ir homeostaziniam ritmui, nes pastebėta, kad nuo XX a. pradžios iki XXI a. pradžios vaikų miego trukmė sutrumpėjo viena valanda $[4,12]$. Tyrimais atskleista, kad vaikų miegą gali sutrikdyti ir IT ekranuose stebimas smurtas ar kitoks grèsmingas turinys $[14,16]$. Ikimokyklinio amžiaus vaikų dažnesni prabudimai nakti yra susiję su suaugusiesiems skirtų filmų žiūrèjimu [15]. Taigi, vaikų prie ekranų leidžiamas laikas bendrai gali sietis su chaotiškesne namų aplinka, nenuosekliomis taisyklèmis, prastesne miego higiena ir nuolatinių miego įpročių neturẻjimu [12, 17].

Suomijos mokslininkai dar $2006 \mathrm{~m}$. publikuotame tyrime teigè, kad svarbus yra ne tik aktyvaus buvimo prie TV ekranų trukmès neigiamas poveikis vaikų miegui, bet ir pasyvus buvimas prie TV bei stebimas turinys [16]. Šio tyrimo rezultatai parode, kad aktyvus TV žiūrẻjimas (kai vaikas pats žiūri televizorių) siejasi su miego-budrumo ritmo sutrikimais, o pasyvus TV žiūrẻjimas (kai vaikas yra tame pačiame kambaryje, kuriame suaugusieji žiūri TV) su miego pradžios ir eigos sutrikimais. Australijos mokslininkai, analizavę abipusius miego trukmès ir buvimo prie ekranų ryšius, taip pat atkreipe dèmesị ị šeimų socialinị ekonominị statusą, tai yra naudojimosi IT ir miego trukmės sąveikos rizika didejja mažesnio socialinio ekonominio sta- tuso šeimose [4]. Tėvų išsilavinimas yra svarbus ir tėvystès, ir vaikų elgesio problemų, ir vaikų naudojimosi IT prietaisais veiksnys [1].

Pirma, duomenų apie mažų vaikų (nuo 1,5 iki 6 metų amžiaus) IT prietaisų naudojimo ịpročius literatūroje kol kas yra mažai, be to, jie nenuoseklūs ir sparčiai keičiasi dèl paties reiškinio (IT naudojimo ịpročių) kaitos. Iš kitos pusès, būtent ikimokyklinio amžiaus vaikų tyrimai šiuo metu yra itin aktualūs, kadangi maži vaikai dèl sparčios raidos ir nervų sistemos plastiškumo yra labiausiai imlūs įvairaus pobūdžio poveikiui. Be to, vaikai paprastai nėra tokie savarankiški, kad vieni, be pagalbos, galètų išsiugdyti būtinus sveikos gyvensenos ịūdžius.

Lietuvoje panašių tyrimų dar nebuvo atlikta. Žinant tikslesnes IT prietaisų naudojimosi apimtis, galima įvertinti jų teigiamą ir neigiamą reikšmę vaikų sveikatai ir raidai, pateikti naudojimosi rekomendacijas tèvams, visuomenei ir gydytojams. Taigi, šiame tyrime siekème sužinoti, kiek laiko 1,5-5 metų amžiaus vaikai leidžia prie įvairių IT prietaisų (ekranų) ir kaip tai siejasi su jų užmigimo bei bendra miego trukme, su būdingais ankstyvoje vaikystẻje vaikų miego ịpročiais, režimu, miego problemomis. Taip pat aiškinomès, ar miego problemos ir miego trukmé siejasi su IT laikymu vaikų poilsio zonoje. Taip pat atsižvelgėme ị kitus svarbius vaiko artimos aplinkos veiksnius, tai yra tèvų išsilavinimą, ugdymo įstaigos lankymą ir pan.

\section{TIRIAMIEJI IR TYRIMO METODAI}

\section{Tyrimo dalyviai}

Šiame tyrime analizuojami 500 vaikų 18-72 mėn. amžiaus duomenys, kurie buvo rinkti $2017 \mathrm{~m}$. balandžio-rugpjūčio mènesiais, bendradarbiaujant su Vilniaus, Kauno, Klaipėdos, Panevėžio ir Alytaus apskričių ikimokyklinio ugdymo įstaigomis, vaikų ligų ir šeimos gydytojais ir duodant tẻvams ar globejjams pildyti popierinę anketą ar pildyti ją internetu, nurodant tyrimo tinklalapio adresą (www.mediavaikai.lt).

$54,4 \%$ tyrime dalyvavusių vaikų sudarė berniukai $(\mathrm{n}=272)$ ir $45,6 \%(\mathrm{n}=228)$ mergaitès. Vaikų amžiaus vidurkis buvo 41,29 mèn. ( $\mathrm{SD}=15,44) .76 \%(\mathrm{n}=380)$ vaiku lankè ikimokyklinio ugdymo ịstaigą. Daugeliu atvejų informaciją apie vaiką pateikè vaiko mama $(91,6 \%$, $\mathrm{n}=458)$, likusiais - vaiko tėvas $(5,8 \%, \mathrm{n}=29)$ ar globejjai $(0,6 \%, n=3), 2 \%$ respondentų $(n=10)$ nenurodè savo ryšio su vaiku. 491 anketą užpildęs tėvas ar globėjas nurodė informaciją apie savo išsilavinimą: $80,3 \%$ iš jų turejjo aukštajị (universitetinị ar neuniversitetinị), $13 \%$ - vidurinị profesinį, likę $(6,7 \%)$ - vidurinị be profesijos ar pagrindini išsilavinimą. $54,5 \%(n=272)$ atvejų informacija apie tyrimo dalyvius buvo gauta, užpildžius popierinę anketos formą, o 45,6 \% (n = 228) - elektroninę.

Tyrimui atlikti gautas Vilniaus regioninio biomedicininių tyrimų etikos komiteto leidimas 
(Nr. 158200-17-906-417). Tyrimą finansuoja Lietuvos mokslo taryba (sutarties Nr. GER-006/2017).

\section{Instrumentai}

Tyrimo anketą sudarè klausimai apie vaiko raidą ir socialinę aplinką, vaiko naudojimąsi IT ir Vaikų elgesio aprašas (Child Behavior Checklist, CBCL/1 1/2-5, T. M. Achenbach ir L. Rescorla, 2000).

\section{Kintamieji ir jų matavimo būdai}

Vaiko raidos ir socialinės aplinkos klausimais buvo siekiama išsiaiškinti įvairias tyrimo dalyvių ir jų aplinkos sociodemografines charakteristikas (amžių, lytị, ugdymo ịstaigos lankymą, tèvų išsilavinimą ir pan.). Taip pat anketoje buvo penki klausimai, skirti nustatyti vaikų miego ypatumus (miego trukmę, miego režimą, miegojimą dieną, užmigimo trukmę ir migdymo aplinkybes).

Vaiko naudojimosi IT klausimai buvo skirti išsiaiškinti, kiek vidutiniškai vaikas praleidžia laiko prie IT prietaisų (atskirai darbo dienomis ir savaitgaliais), koks tos veiklos pobūdis, ar vaiko kambaryje yra laikomi IT prietaisai ir, jei taip, kokie.

Vaikų miego sunkumai buvo vertinami pagal Vaiko elgesio aprašo (CBCL/11/2-5) Miego sunkumų skalę. Šią skalę sudaro 7 teiginiai apie vaiko miegą ar su miegu susijusị elgesị (pvz., vaikas „sunkiai užmiega“, „naktimis dažnai atsibunda“" ir pan.), kuriuos tėvai ar globejjai vertino nuo 0 (teiginys neteisingas konkretaus vaiko atžvilgiu) iki 2 (teiginys visiškai arba dažniausiai teisingas konkretaus vaiko atžvilgiu). Nustatyta, kad lietuviškosios CBCL/11/2-5 versijos miego sunkumų skalès Cronbacho $\alpha$ lygis yra 0,66 (Jusienè ir Raižienè, 2006), šiame tyrime $-0,65$.

\section{Statistinis duomenu apdorojimas}

Statistiniam duomenų skaičiavimui buvo naudota IBM SPSS 24.0 programa. Statistinei duomenų analizei taikyti šie metodai: aprašomoji statistika naudota vidurkiams ir standartiniams nuokrypiams skaičiuoti; ranginių kintamųjų ir ne pagal normalụji skirstinị pasiskirsčiusių intervalinių kintamųjų (nakties miego trukmés, IT naudojimo trukmès, tyrimo dalyvių amžiaus) skirstinių palyginimui tarp grupių naudotas Mann-Whitney-Wilcoxon kriterijus dviem nepriklausomoms imtims (kai lyginamos dvi grupės) ir Kruskal-Wallis kriterijus (kai lyginamos daugiau nei dvi grupės); dviejų ranginių kintamųjų, ranginio ir intervalinio kintamujjų arba dviejų intervalinių kintamųjų, pasiskirsčiusių ne pagal normalujji skirstinị (pvz., vaikų amžiaus ir jų patiriamų miego sunkumų) naudota Spearman koreliacija; dviejų kategorinių kintamųjų tarpusavio sąsajoms tikrinti (pvz., ikimokyklinès įstaigos lankymo ir dienos miego, miego sunkumų ir IT prietaiso buvimo kambaryje, kur vaikas miega) naudotas Chi kvadrato požymių homogeniškumo kriterijus.

\section{REZULTATAI}

\section{Vaikų miego ypatumų ir demografinių charakteristiku sąsajos}

Didžioji dalis tyrime dalyvavusių vaikų nakti miega vidutiniškai 9 ar 10 valandų (1 pav.). Trumpiau naktị miega vyresni vaikai: Spearman koreliacija tarp nakties miego trukmès ir vaiko amžiaus $r=-0,23, p<0,001$. Vidutinè nakties miego trukmé, nesusijusi su vaiko lytimi: mergaičiu nakties miego trukmès rangų vidurkis $\mathrm{M}=2,43(\mathrm{SD}=0,052)$, berniuku $-\mathrm{M}=2,42(\mathrm{SD}=0,049)$, $\mathrm{Z}=-0,121, \mathrm{p}=0,903$. Beveik visi $(95,3 \%) 8$ val. ir mažiau naktį miegantys vaikai ir visi 7 val. ir mažiau naktị miegantys vaikai miega dieną.

Dieną kasdien miega 77 \% 1,5-5 m. vaikų, 18 \% vaikų dieną miega kartais ir tik $4 \%$ nemiega visai. Nuolat dieną miega jaunesni vaikai: kasdien miegančių vaikų amžiaus vidurkis mėnesiais - $\mathrm{M}=33,73(\mathrm{SD}=0,73)$, kartais miegančių $\mathrm{M}=53,10(\mathrm{SD}=1,33)$, niekada nemiegančių $\mathrm{M}=57,35(\mathrm{SD}=2,41), \chi^{2}=92,0560, \mathrm{df}=2, \mathrm{p}<0,001$. Dienos miegas susijęs su ikimokyklinės ugdymo ịstaigos lankymu: iš kasdien miegančių vaikų darželio nelanko $17,8 \%$, iš kartais miegančių ar visai nemiegančių dieną vaikų darželio nelanko atitinkamai 3,3 ir $5 \%$ vaikų $\left(\chi^{2}=13,753 \mathrm{df}=2, \mathrm{p}=0,001\right)$.

Vaikų amžius susijęs ir su kitomis vaikų miegą aprašančiomis charakteristikomis. Nuolatinis miego režimas, kai užmiegama ir atsibundama visada tuo pačiu metu, būdingas jaunesniems vaikams: nuolatinị miego režimą turinčių vaikų $(\mathrm{N}=324)$ amžiaus mėnesiais vidurkis $\mathrm{M}=40,05(\mathrm{SD}=0,88)$, neturinčių nuolatinio miego režimo $(\mathrm{N}=171)$ vaikų amžiaus mėnesiais vidurkis $\mathrm{M}=43,78(\mathrm{SD}=1,13), \mathrm{Z}=-2,73, \mathrm{p}=0,006$. Užmigimo trukmė su vaikų amžiumi nesusijusi (užmiegančių per mažiau nei 15 min. vaikų $(\mathrm{N}=98)$ amžiaus mėnesiais vidurkis $-\mathrm{M}=43,94(\mathrm{SD}=1,56)$, užmiegančių per 15-30 min. $(\mathrm{N}=301)$ amžiaus mėnesiais vidurkis $\mathrm{M}=40,14(\mathrm{SD}=0,92)$, užmiegančių per daugiau nei 30 min. $(\mathrm{N}=92)$ amžiaus mėnesiais vidurkis $\left.\mathrm{M}=41,80(\mathrm{SD}=1,56), \chi^{2}=4,59, \mathrm{df}=2, \mathrm{p}=0,101\right)$. Jau-

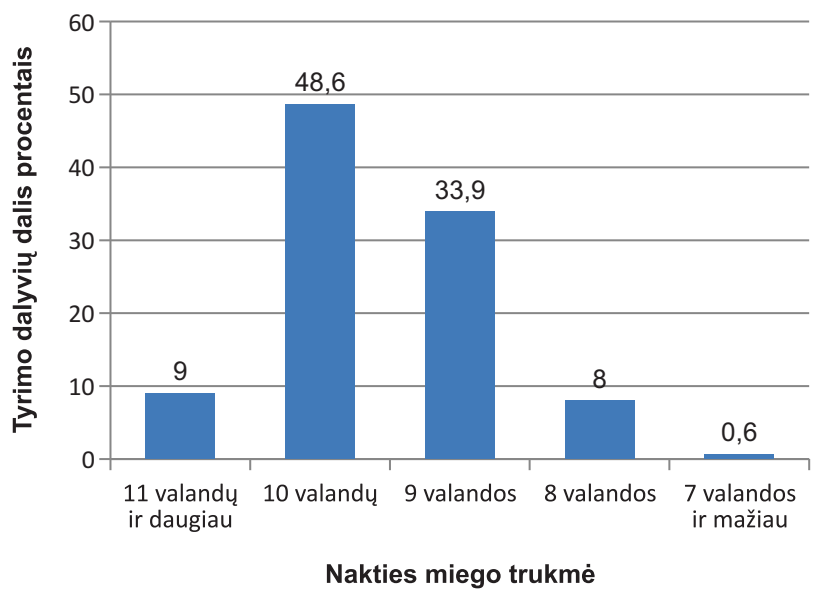

1 pav. Tiriamųjų pasiskirstymas pagal nakties miego trukmę $(\mathbf{N}=\mathbf{4 9 0})$ 
nesni vaikai dažniau atsibunda naktį: dažnai atsibundančių vaikų $(\mathrm{N}=136)$ amžiaus ménesiais vidurkis $\mathrm{M}=36,96(\mathrm{SD}=1,29)$, vaikų, kuriems dažni atsibudimai nebūdingi $(\mathrm{N}=354)$, amžiaus mènesiais vidurkis $\mathrm{M}=43,29(\mathrm{SD}=0,81), \mathrm{Z}=-4,16$, $\mathrm{p}<0,000$. Miego kokybè su amžiumi didẻja: nustatyta silpna statistiškai reikšminga neigiama koreliacija tarp vaiku amžiaus ir jų patiriamų miego sunkumų: $r=-0,097, p=0,033$. Miego sunkumų turinčiu vaikų, kurių CBCL Miego skalès įvertis patenka į Ribos ar Nuokrypio inter-

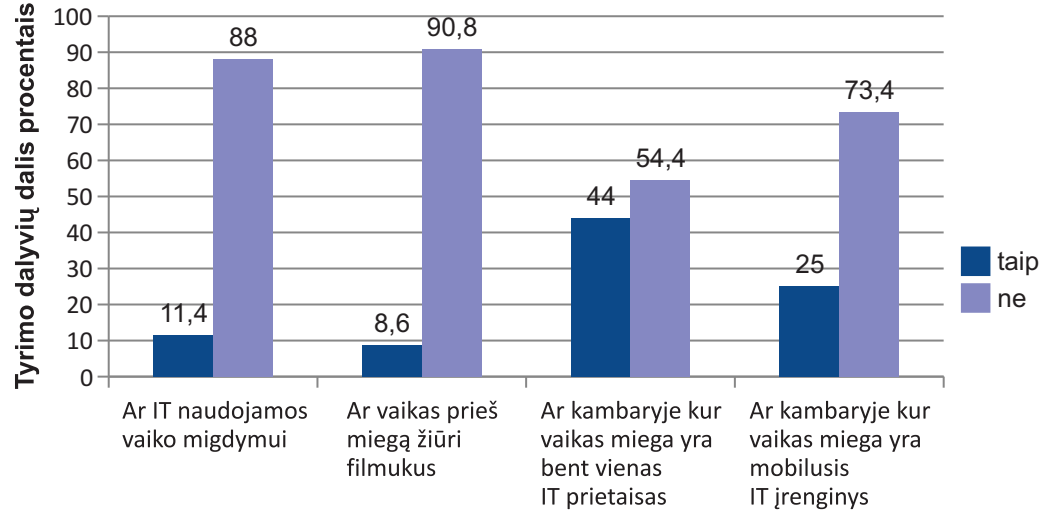

2 pav. Vaiko miego aplinka ir IT naudojimas valą, tiriamojoje imtyje yra 22. Šių vaikų miego sunkumų lygis vertintinas kaip miego sutrikimo rizika. Nenustatyta sąsajų tarp miego sutrikimo rizikos ir demografinių charakteristikų.

\section{Informacinès technologijos vaikų miego aplinkoje}

Maždaug pusės tyrime dalyvavusių vaikų kambariuose, kuriuose jie miega ir ilsisi, yra laikomas bent vienas IT prietaisas, neatsižvelgiant ị tai, kad didžioji mažų vaikų dalis migdomi, nenaudojant IT prietaisų; populiariausia veikla, atliekama vaikų prieš miegą, yra filmukų žiūrèjimas (2 pav.). Be IT prietaisų kambaryje miega vyresni vaikai: vaikų, kurių miego erdveje yra IT prietaisai $(\mathrm{N}=220)$, amžiaus mènesiais vidurkis $-\mathrm{M}=38,77(\mathrm{SD}=1,04)$; vaikų, kurių miego erdvejje nèra IT prietaisų $(\mathrm{N}=272)$, amžiaus mènesiais vidurkis $-\mathrm{M}=43,51(\mathrm{SD}=0,936)$, $\mathrm{Z}=-3,41, \mathrm{p}=0,001$. Miego ir poilsio erdvę be IT prietaisu savo vaikams dažniau sukuria aukštajį išsilavinimą turintys tèvai: kambaryje, kuriame laikomi IT prietaisai, vaikus migdo $68,1 \%$ aukštojo išsilavinimo neturinčių mamų, 62,3 \% aukštaji neuniversitetinị išsilavinimą turinčių mamų ir 35,9\% aukštajị universitetinị išsilavinimą turinčiu mamu $\left(\chi^{2}=37,14 ; \mathrm{df}=2, \mathrm{p}<0,001\right)$ ir atitinkamai 62,5, 46,7 ir 31,9\% tečiu $\left(\chi^{2}=33,96 ; d f=2, p<0,001\right)$.

Naudotis IT prietaisais ir žiūrèti filmukus prieš miegą savo vaikams leidžia vyresnių vaikų tèvai: vaikų, nesinau-

dojančiu IT prietaisais prieš miegą $(\mathrm{N}=440)$, amžiaus mènesiais vidurkis $-M=40,83(S D=0,75)$, besinaudojančių $(N=57)-M=45,13(S D=1,79), Z=-2,09, p=0,037$; vaikų, nežiūrinčių prieš miegą filmukų ( $\mathrm{N}=454)$, amžiaus mènesiais vidurkis $-\mathrm{M}=40,83(\mathrm{SD}=0,731)$, žiūrinčių $(N=43)-M=46,51(S D=2,08), Z=-2,35, p=0,019$. Tendencija naudoti filmukus, kaip vaikų migdymo priemonę, yra susijusi ir su vaiko mamos (bet ne tèvo) išsilavinimu: filmukus prieš miegą žiūrèti vaikams leidžia 16,3\% aukštojo išsilavinimo neturinčių mamų, 9,4 \% aukštajj neuniversitetinị išsilavinimą turinčių mamų ir tik 6,6\% aukštajji universitetinị išsilavinimą turinčių ma$\operatorname{muc}\left(\chi^{2}=8,432 ; \mathrm{df}=2, \mathrm{p}=0,015\right)$.

\section{Vaikų miego ypatumų ir informacinių technologijų naudojimo sąsajos}

Siekiant nustatyti, ar skiriasi ilgiau ir trumpiau miegančių vaikų naudojimosi IT ịpročiai, tyrime dalyvavę vaikai pagal jų nakties miego trukmę buvo suskirstyti į dvi grupes: ilgiau naktị miegančius (9 val. ir daugiau) ir trumpiau naktị miegančius ( 8 val. ir mažiau). Palyginus šias grupes pagal ịvairių IT prietaisu naudojimo trukmę ir bendro prie ekranų praleisto laiko trukmę darbo dienomis ir savaitgaliais, nustatyta, kad trumpiau naktị miega tie vaikai, kurie ilgiau naudojasi kompiuteriu darbo die-

Lentelè. Ilgiau (9 val. ir daugiau) ir trumpiau (8 val. ir mažiau) naktị miegančių vaikų naudojimosi IT trukmės skirtumai

\begin{tabular}{|c|c|c|c|c|c|}
\hline & & Miegantys ilgiau $(n=448)$ & Miegantys trumpiau $(n=42)$ & & \\
\hline & & M (SD) & M (SD) & $\mathbf{U}$ & p \\
\hline \multirow{5}{*}{$\begin{array}{l}\text { Darbo } \\
\text { dienomis }\end{array}$} & Ekranai, iš viso & $3,24(0,63)$ & $3,42(0,21)$ & 8769,50 & 0,558 \\
\hline & TV & $2,65(0,07)$ & $2,81(0,26)$ & 8658,50 & 0,844 \\
\hline & Telefonas & $1,70(0,05)$ & $1,94(0,23)$ & 8314,00 & 0,522 \\
\hline & Planšetinis kompiuteris & $1,49(0,05)$ & $1,53(0,15)$ & 8352,00 & 0,525 \\
\hline & Kompiuteris & $1,35(0,04)$ & $1,81(0,21)$ & 6734,00 & 0,004 \\
\hline \multirow{5}{*}{$\begin{array}{l}\text { Poilsio } \\
\text { dienomis }\end{array}$} & Ekranai, iš viso & $3,91(0,07)$ & $4,47(0,27)$ & 7039,50 & 0,016 \\
\hline & TV & $3,14(0,08)$ & $3,31(0,30)$ & 8554,50 & 0,766 \\
\hline & Telefonas & $1,86(0,06)$ & $2,28(0,28)$ & 7974,50 & 0,300 \\
\hline & Planšetinis kompiuteris & $1,65(0,06)$ & $1,69(0,22)$ & 8384,50 & 0,880 \\
\hline & Kompiuteris & $1,45(0,05)$ & $2,06(0,27)$ & 6821,50 & $\mathbf{0 , 0 2 2}$ \\
\hline
\end{tabular}


nomis ir laisvadieniais bei daugiau laiko leidžia prie ekranų laisvadieniais (lentelè). Tiesa, šie naudojimosi IT kintamieji yra susiję su vaikų amžiumi: vyresni vaikai daugiau naudojasi kompiuteriu darbo dienomis $(\mathrm{r}=0,17, \mathrm{p}<0,001)$ ir laisvadieniais $(\mathrm{r}=0,17, \mathrm{p}<0,001)$ bei praleidžia daugiau laiko prie ekranų laisvadieniais $(\mathrm{r}=0,24, \mathrm{p}<0,001)$, bet ne darbo dienomis $(\mathrm{r}=0,08$, $\mathrm{p}<0,084)$. Nakties miego trukmé susijusi ir su IT naudojimu prieš miegą: iš trumpiau naktị miegančių vaikų IT prieš miegą naudojasi $21,4 \%$, o iš ilgiau miegančių perpus mažesnè dalis $(10,5 \%), \chi^{2}=4,54 ; \mathrm{df}=1$, $\mathrm{p}=0,033)$.

Miego sunkumai, vertinami CBCL miego skale, taip pat susiję su naudojimosi IT trukme. Miego sutrikimo riziką turintys vaikai $(\mathrm{N}=22)$ vidutiniškai ilgiau už sunkumų neturinčius $(\mathrm{N}=470)$ žiūri TV laisvadieniais (sunkumų neturinčių vaikų naudojimosi IT trukmės rangų vidurkis $M=3,19(\mathrm{SD}=0,78)$, sunkumų turinčiuc $\mathrm{M}=2,30(\mathrm{SD}=0,33), \mathrm{Z}=-2,46, \mathrm{p}=0,014)$ ir ilgiau naudojasi kompiuteriu laisvadieniais (sunkumų neturinčių vaikų naudojimosi IT trukmès rangų vidurkis $\mathrm{M}=1,47(\mathrm{SD}=0,05)$; sunkumų turinčių $\mathrm{M}=1,95(\mathrm{SD}=0,32) ; \mathrm{Z}=-2,01, \mathrm{p}=0,045)$.

Vaikams, kurių kambaryje, kur jie miega ir ilsisi, yra bent vienas IT prietaisas, būdingas aukštesnis CBCL Miego sunkumų skalès įvertis nei tiems, kurių poilsio kambaryje IT prietaisų nèra (atitinkamai $\mathrm{M}=3,17(\mathrm{SD}=0,16)$ ir $\mathrm{M}=2,61(\mathrm{SD}=0,14), \mathrm{Z}=-2,85, \mathrm{p}=0,004)$. Didesnès dalies sunkiai užmiegančių vaikų miego erdvejje laikomi nešiojamieji IT prietaisai (telefonai ir (ar) planšetiniai kompiuteriai): 31,4 \% vaikų, kurių tėvai nurode juos sunkiai užmiegant, ir 22,3\% vaikų, kurių tèvai nenurodė juos patiriant sunkumų užmiegant, miego erdvėje laikomas nešiojamasis IT prietaisas $\left(\chi^{2}=4,75 ; \mathrm{df}=1, \mathrm{p}=0,038\right)$ (3 pav.).

Analizuojant vaikų užmigimo trukmės sąsajas su migdymo praktikomis, nustatyta, kad didesnė dalis lėčiau užmiegančių vaikų prieš miegą žiūri filmukus: filmukus prieš miegą žiūri 15,2 \% ilgiau nei per 30 minučių užmiegančių vaikų, 7,6 \% per 15-30 minučių užmiegančių vaikų ir tik $5,1 \%$ per trumpiau nei 15 min. užmiegančių vaikų $\left(\chi^{2}=7,04 ; \mathrm{df}=2, \mathrm{p}=0,030\right)(4 \mathrm{pav}$.$) .$

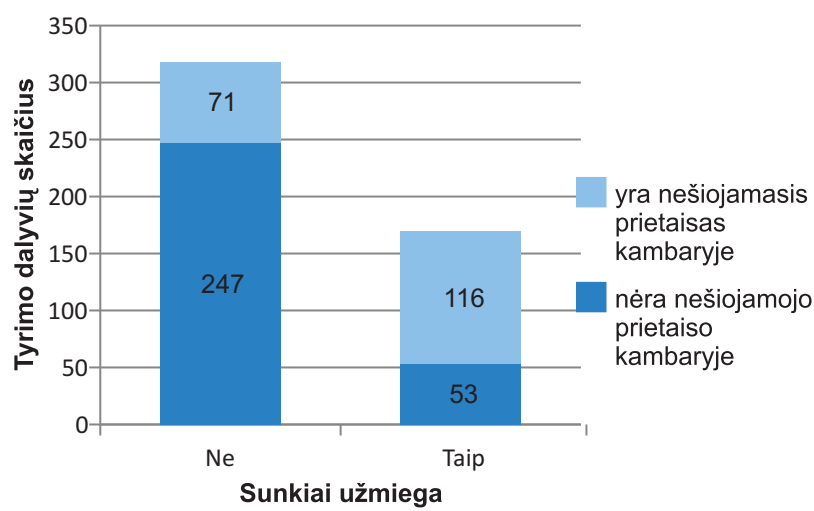

3 pav. Tyrimo dalyvių sunkumai užmigti ir nešiojamojo IT prietaiso buvimas kambaryje, kur vaikas miega ir ilsisi

\section{REZULTATU APTARIMAS}

Remiantis Nacionalinės Miego Organizacijos (angl. $\mathrm{Na}$ tional Sleep Foundation) pateiktomis rekomendacijomis, 1-2 metų amžiaus vaikai turètų miegoti nuo 11 iki 14 valandų (leidžiamos ribos - nuo 9 iki 10 val.), o 3-5 metų amžiaus vaikai - nuo 10 iki 13 valandų (leidžiamos ribos nuo 8 iki 9 val.) [18]. Daugiausia mūsų tyrime dalyvavusių vaikų paros miego trukmė yra pakankama. Taip pat stebimas nuoseklus vyresnių vaikų miego trukmès mažejimas, lyginant su jaunesniais. Pastebèta, kad per paskutinị šimtmetị vaikų ir paauglių (5-18 m. amžiaus) miego trukmè sutrumpèjo apie 1 valandą [19]. Europoje (Švedijoje) atlikto tyrimo metu nustatyta, kad per 28 metus vaikų ir paauglių nuo 11 iki 15 metu amžiaus miego trukmè sutrumpejjo. Vertinant tarp lyčių, berniukai eina miegoti vẻliau, taip pat jų miegas trumpesnis. Tai gali turèti neigiamos ịtakos mokslo rezultatams, psichinei sveikatai ir pažintiniams gebẻjimams [20]. Išsamių duomenų apie jaunesnių vaikų miego trukmės pokyčius kol kas nèra. Manoma, kad šiandien vaikų miego poreikis yra mažesnis, nei buvo jų tėvų ar senelių. Todèl svarbus ir tolimesnis vaikų miego trukmès stebejimas ir vertinimas. Taip pat, tiriant paauglių miegą, nustatyta, kad sezoniškumas turi įtakos miegui. Vasarą miego pradžia beveik valanda vèlesnè nei žiemą [21]. Todèl manoma, kad, vertinant vaikų miegą, reikètų atsižvelgti ir į metų laikus.

Mūsų tyrimo rezultatai rodo, kad mažų vaikų miego kokybė yra susijusi su IT prietaisų buvimu jų miego erdvėje. Beveik pusės 1,5-5 metų amžiaus vaikų miegamuosiuose ar poilsio erdveje yra laikomi IT prietaisai. IT prietaisus poilsio erdvejje turintys vaikai sunkiau užmiega, be to, jie bendrai turi daugiau miego problemų, rodančių miego sutrikimo riziką. Kanados tyrẻjai taip pat nustaté, kad kuo daugiau IT prietaisų yra vaiko kambaryje, tuo ilgesnè šių prietaisų naudojimo trukmè, mažesnis miego efektyvumas, todèl rekomenduojama vengti IT prietaisų kambaryje, kuriame miegama [22].

Remiantis mūsų tyrimo rezultatais, galima daryti prielaidą, kad aukštesnị išsilavinimą turintys tèvai daugiau dèmesio skiria vaiko miego higienai, todèl rečiau leidžia vaikams naudotis IT prietaisais prieš miegą, taip pat jų vengia

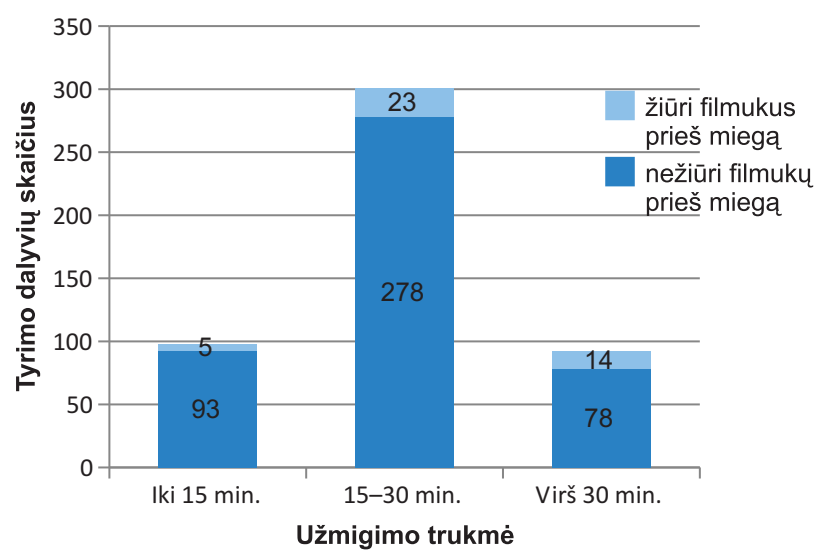

4 pav. Tyrimo dalyvių užmigimo trukmẻ ir filmukų žiūrẻjimas prieš miegą 
miego erdvėje. Tai gali būti susiję ir su tuo, kad aukštesnio išsilavinimo tèvai paprastai turi geresnes gyvenimo sąlygas (pvz., didesni gyvenamąji plotą), taigi gali vaikams sudaryti ramesnę, palankesnę miegui asmeninę erdvę. Kituose tyrimuose taip pat teigiama, kad geresnè vaiko miego kokybė susijusi ir su visos šeimos gyvenimo kokybe [23, 24].

Nuolatinis naktinis miego režimas turi teigiamą poveikị vaikų miego kokybei, kalbos raidai, emocijų ir elgesio reguliacijai, yra svarbus tèvų ir vaiko prieraišumo formavimuisi [25]. Vis dèlto gauti tyrimo rezultatai rodo, kad nuolatinis miego režimas būdingesnis tik jaunesniems vaikams. Todèl reikètų atkreipti didesnị dėmesị ị vyresnių vaikų miego pradžios laiką.

Anglijoje 2015 m. birželio - 2016 m. kovo mèn. atlikto tyrimo duomenys atskleidžia, kad dažnesnis 6-36 mėnesių amžiaus vaikų naudojimasis IT prietaisais yra statistiškai patikimai susijęs su ilgiau trunkančiu užmigimu ir trumpesne miego trukme [26]. Neigiamas miego trukmès, bendrai miego kokybės ir IT naudojimo ryšys pastarąij dešimtmeti stebimas ir kituose moksliniuose tyrimuose [12, 27]. Mūsų tyrimo rezultatai taip pat patvirtina IT ir miego trukmès neigiamą ryšị - naktị trumpiau miega tie vaikai, kurie ilgiau naudojasi kompiuteriu darbo dienomis ir laisvadieniais, daugiau laiko leidžia prie ịvairių ekranų poilsio dienomis, taip pat dažniau naudojasi IT prieš miegą.

Amerikos pediatrų draugijos (AAP) 2013 metų gairèse rekomenduojama vaikams iki 2 metų amžiaus visai neleisti naudotis IT prietaisais, o vyresniems nei 2 metų amžiaus vaikams naudojimą riboti iki 2 valandų per dieną [2]. Remiantis šiomis gairèmis, tik mažuma Lietuvoje gyvenančių vaikų IT naudojimo trukmė atitinka šias rekomendacijas. AAP gaires planuojama atnaujinti ir peržiūrèti, nes ypač sparti IT pažanga keičia mūsų kasdienybę greičiau, nei specialistai spejja tirti galimas tokių pokyčių pasekmes. JAV atlikto tyrimo duomenimis, nuo 2011 iki 2013 m. labai (nuo 10 iki $38 \%$ ) padidejo vaikų, jaunesnių nei 2 metu amžiaus, IT prietaisų naudojimas. Šio tyrimo autoriai rekomenduoja tokio amžiaus vaikams ne drausti naudotis IT, bet riboti iki 30 min. - 1 val. per dieną, nes tokio amžiaus vaiko budrumas per parą trunka nuo 8 iki 12 valandų [27].

Mūsų tyrimas atskleidè, kad ankstyvame amžiuje IT prietaisų naudojimas yra susijęs su miego problemomis (prabudimais, sunkumais užmigti ir pan.), ilgesniu užmigimu ir trumpesne miego trukme. Užsitęsus šioms miego problemoms, gali sutrikti vienas iš miegą reguliuojančių biologiniu procesų - miego-budrumo ritmas.

Susirūpinimą kelia tai, kad jau mažiems vaikams sutrikdomas miego-budrumo ritmas, kas ateityje gali nulemti uždelstos miego fazès sutrikimą. Klinikiniais tyrimais įrodyta kokybiško vaikų miego svarba kognityvinei ir emocijų raidai [28]. Taigi, tėvai turètų kontroliuoti prie IT ekranų praleistą laiką ir žiūrimą turinị.

Šis tyrimas yra tik pirmas mėginimas aiškintis mažų vaikų IT naudojimo apimtis ir tai, kaip tai siejasi su jų miego trukme bei kokybe. Tolesniuose tyrimuose svarbu aiškintis ne tik buvimo prie ekranų trukmę, bet ir turini (t. y. ką vaikai stebi ekranuose). Būtent turinys, kai kurių užsie- nio tyrimų rezultatais, gali būti svarbesnis. Dar 2006 m. atliktas tyrimas atskleidè, kad suaugusiųų programų žiūrèjimas ir pasyvus televizijos žiūrẻjimas reikšmingai asocijuojasi su miego problemomis, o aktyvus vaikiškų programų žiūrẻjimas miegui įtakos neturi [16].

Atlikus ir papildžius duomenis didesnès apimties tyri$\mathrm{mu}$, svarbu parengti pagrịstas rekomendacijas ir informuoti tèvus bei visuomenę apie ankstyvoje vaikysteje miego kokybę lemiančias išorines priežastis.

\section{IŠVADOS}

1 Atlikto tyrimo rezultatai atskleidè, kad dauguma 18-72 mèn. amžiaus vaikų naktị miega 9-10 valandų. Beveik visi (95,3 \%) 8 val. ir mažiau naktị miegantys ir visi 7 val. ir mažiau naktị miegantys vaikai miega dieną. Net $77 \%$ vaikų kasdien miega dieną. Jaunesniems vaikams yra būdingas miego režimas, bet dažnesni prabudimai naktị.

2. Maždaug pusės tyrime dalyvavusių vaikų miego ir poilsio zonose yra bent vienas IT prietaisas. Žemesnio išsilavinimo tėvų vaikai dažniau turi IT prietaisų kambaryje, kuriame miega, ir jiems leidžiama prieš miegą žiūrèti filmukus.

3. Vaikams, kurių kambaryje, kur jie miega ir ilsisi, yra bent vienas IT prietaisas, būdingas reikšmingai didesnis miego sunkumų skalès įvertis nei tiems, kurių poilsio kambaryje IT prietaisų nėra. Ikimokyklinio amžiaus vaikai, kurie savo (poilsio) kambaryje turi IT prietaisų, užmiega sunkiau.

4. Trumpiau nakti miega vaikai, kurie ilgiau naudojasi kompiuteriu darbo dienomis ir laisvadieniais. Jie taip pat daugiau laiko leidžia prie ekranų poilsio dienomis. Bendrai ilgesnè buvimo prie įvairių IT prietaisų trukmė būdinga vaikams, turintiems miego sutrikimo riziką.

\section{PADE்KA}

Tyrimą ir straipsnio rengimą finansavo Lietuvos mokslo taryba (sutartis Nr. GER-17050). Dėkojame Vilniaus universiteto psichologijos magistrantams, padejusiems surinkti ir suvesti tyrimo duomenis: Simonui Bereniui, Alinai Pajëdienei, Laurai Vitkei. Taip pat labai dèkojame mažus vaikus auginantiems tėvams, kurie atsakè į tyrimo anketos klausimus.

\section{Literatūra}

1. Anand S, Krosnick JA. Demographic predictors of media use among infants, toddlers, and preschoolers. American Behavioral Scientist 2005; 48(5): 539-61. https://doi.org/10.1177/ 0002764204271512

2. American Academy of Pediatrics. Policy statement: Children, adolescents, and the media. Pediatrics 2013; 132(5): 958-61. https://doi.org/10.1542/peds.2013-2656 
3. Lauricella AR, Wartella E, Rideout V. Young children's screen time: The complex role of parent and child factors. Journal of Applied Developmental Psychology 2015; 36: 11-7. https://doi.org/10.1016/j.appdev.2014.12.001

4. Magee CA, Lee JK, Vella SA. Bidirectional relationships between sleep duration and screen time in early childhood. JAMA Pediatr 2014; 168(5): 465-70. https://doi.org/ 10.1001/jamapediatrics.2013.4183

5. Rosen LD, Lim AF, Felt J, Carrier LM, et al. Media and technology use predicts ill-being among children, preteens and teenagers independent of the negative health impacts of exercise and eating habits. Computers Human Behavior 2014; 35: 364-75. https://doi.org/10.1016/j.chb.2014.01.036

6. Christakis DA, Ebel BE, et al. Television, video and computer game usage in children under 11 years of age. Journal of Pediatrics 2004; 145(5): 652-6. https://doi.org/10.1016/ j.jpeds.2004.06.078

7. Nathanson AI, Alade F, Sharp M, et al. The relation between television exposure and executive function among preschoolers. Developmental Psychology 2014; 50(5): 1497-506. https://doi.org/10.1037/a0035714

8. Radesky JS, Silverstein M, Zuckerman B, Christakis DA. Infant self-regulation and early childhood media exposure. Pediatrics 2014; 133: e1172-8. https://doi.org/10.1542/ peds.2013-2367

9. McFarlane E, Dodge RA, Burrell L, et al. The importance of early parenting in at-risk families and children's social-emotional adaptation to school. Acad Pediatr 2010; 10(5): 330-7. https://doi.org/10.1016/j.acap.2010.06.011

10. Foster EM, Watkins S. The value of reanalysis: TV viewing and attention problems. Child Development 2010; 81(1): 368-75. https://doi.org/10.1111/j.1467-8624.2009. 01400.x

11. Diamond A, Lee K. Interventions shown to aid executive function development in children 4 to 12 years old. Science 2011; 333(6045): 959-64. https://doi.org/10.1126/ science. 1204529

12. Bathory E, Tomopoulos S. Sleep regulation, physiology and development, sleep duration and patterns, and sleep hygiene in infants, toddlers, and preschool-age children. Current Problems in Pediatric and Adolescent Health Care 2017; 47: 29-42. https://doi.org/10.1016/j.cppeds.2016.12.001

13. Cain N, Gradisar M. Electronic media use and sleep in schoolaged children and adolescents: A review. Sleep Med 2010; 11(8): 735-42. https://doi.org/10.1016/j.sleep.2010.02.006

14. Hale L, Guan S. Screen time and sleep among school-aged children and adolescents: a systematic literature review. Sleep Med Rev 2015; 21: 50-8. https://doi.org/10.1016/ j.smrv.2014.07.007

15. Yland J, Guan S, Emanuele E, Hale L. Interactive vs passive screen time and nighttime sleep duration among school-aged children. Sleep Health 2015; 1(3): 191-6. https://doi.org/ 10.1016/j.sleh.2015.06.007

16. Paavonen JE, Pennonen M, Roine M, et al. TV exposure associated with sleep disturbances in 5- to 6-year old children. Journal of Sleep Research 2006; 15(2): 154-61. https://doi.org/10.1111/j.1365-2869.2006.00525.x

17. Thompson DA, Christakis DA. The association between television viewing and irregular sleep schedules among children less than 3 years of age. Pediatrics 2005; 116(4): 851-6. https://doi.org/10.1542/peds.2004-2788

18. National Sleep Foundation. Available at: https://sleepfoundation.org/excessivesleepiness/content/ how-much-sleep-do-babies-and-kids-need
19. Matricciani L, Olds T, Petkov J. In search of lost sleep: secular trends in the sleep time of school-aged children. Sleep Med Rev 2012; 16(3): 203-11. https://doi.org/10.1016/ j.smrv.2011.03.005

20. Norell-Clarke A, Hagquist C. Changes in sleep habits between 1985 and 2013 among children and adolescents in Sweden. Scandinavian Journal of Public Health 2017; 45(8): 869-77. https://doi.org/10.1177/1403494817732269

21. Quante M, Wang R, Weng J, et al. Seasonal and weather variation of sleep and physical activity in 12-14 year old children. Behavioral Sleep Medicine 2017; 18: 1-13. https://doi.org/10.1080/15402002.2017.1376206

22. Chaput JP, Leduc G, Boyer C, et al. Electronic screens in children's bedrooms and adiposity, physical activity and sleep: Do the number and type of electronic devices matter? Can J Public Health 2014; 105(4): e273-9. https://doi.org/ 10.17269/cjph.105.4511

23. Buxton OM, Chang A-M, et al. Sleep in the modern family: protective family routines for child and adolescent sleep. Sleep Health 2015; 1(1): 15-27. https://doi.org/10.1016/ j.sleh.2014.12.002

24. Halal CS, Nunes ML. Education in children's sleep hygiene: which approaches are effective? A systematic review. J Pediatr 2014; 90: 449-56. https://doi.org/10.1016/ j.jped.2014.05.001

25. Nagy E, Moore S, et al. Parental social capital and children's sleep disturbances. Sleep Health 2016; 2(4): 330-4. https://doi.org/10.1016/j.sleh.2016.09.003

26. Mindell JA, Williamson AA. Benefits of a bedtime routine in young children: Sleep, development, and beyond. Sleep Med Rev 2017; pii: S1087-0792(17)30048-5.

27. Cheung CHM, Bedford R, et al. Daily touchscreen use in infants and toddlers is associated with reduced sleep and delayed sleep onset. Scientific Reports 2017; 7: 46104. https://doi.org/10.1038/srep46104

28. Christakis DA. Interactive media use at younger than the age of 2 years: time to rethink the American Academy of Pediatrics guideline? JAMA Pediatr 2014; 168(5): 399-400. https://doi.org/10.1001/jamapediatrics.2013.5081

29. Lavigne JV, Arend R, Rosenbaum D, et al. Sleep and behavior problems among preschoolers. J Dev Behav Pediatr 1999; 20: 164-9. https://doi.org/10.1097/00004703199906000-00005

\section{R. Praninskienė, R. Jusienè, I. Laurinaitytė, L. Petronytė, L. Rakickienė, V. Urbonas}

\section{ELECTRONIC MEDIA USE AND SLEEP IN TODDLERHOOD AND PRESCHOOL AGE}

\section{Summary}

Introduction and aim. The use of modern information technology (IT) can affect children's physical and mental health. The aim of the present study was to find out how long young children use different IT devices (screens) and whether the IT usage was associated with sleep habits, routines, sleep duration and sleep problems.

Methods. We analyzed data of 500 children, whose age was between 18-72 months $(M=41.29, S D=15.44)$. Parents of toddlers and preschool children from different regions of Lithuania were asked to fill in questionnaires about their children's mental and physical health and the use of information technologies and screen time on workdays and weekends. The study was carried 
out in April-August 2017. The survey questionnaire contained questions about the child's development, social environment, and usage of IT devices. Children's sleep problems were assessed using the Child's Behavior Checklist (CBCL / 1 1/2-5).

Results. The study results revealed that most children's sleep duration was $9-10$ hours per night. $95.3 \%$ of children, who slept 8 hours, and all children, who slept 7 hours during night, slept also during daytime. $77 \%$ of children at this age slept during the day. Younger children had habits and routine before sleep time, but they had also more awakenings during the night time. About half of the children had at least one IT device in their sleeping room. Children of parents with lower education were more likely to have an IT device in the sleeping room, and they were permitted to watch movies before bedtime. Also, children who had an IT device in their sleeping room had more difficulties initiating sleep, and they had more sleep problems (reaching the borderline or clinical level). Children who were sleeping shorter than 8 hours at night were using computers longer during the week and on weekends, they also spent more time on other screens during the weekends. Finally, the longer overall screen time was prominent in the group of children who had the highest scores of sleep problems.

Conclusions. This study supports recent findings in other countries confirming that the use of IT in the early childhood before going to sleep and having devices in bedroom are associated with sleep problems, difficulties initiating sleep and shorter sleep duration.

Keywords: electronic media, early childhood, sleep problems, sleep duration.

Gauta:

Priimta spaudai:

20180103

20180206 